Article

\title{
The 2019 Eruption Dynamics and Morphology at Ebeko Volcano Monitored by Unoccupied Aircraft Systems (UAS) and Field Stations
}

\author{
Thomas R. Walter ${ }^{1, *(D)}$, Alexander Belousov ${ }^{2}$, Marina Belousova ${ }^{2}$, Tatiana Kotenko ${ }^{2}$ and \\ Andreas Auer ${ }^{3}$ (D) \\ 1 Department of Geophysics, GFZ Potsdam, Telegrafenberg, 14473 Potsdam, Germany \\ 2 Institute of Volcanology and Seismology, FED RAS, 683006 Petropavlovsk, Russia; bel@kscnet.ru (A.B.); \\ belousov@mail.ru (M.B.); sinarka2017@mail.ru (T.K.) \\ 3 Department of Geoscience, Shimane University, Matsue 690-8504, Japan; auer@riko.shimane-u.ac.jp \\ * Correspondence: twalter@gfz-potsdam.de
}

Received: 20 May 2020; Accepted: 16 June 2020; Published: 18 June 2020

\begin{abstract}
Vulcanian explosions are hazardous and are often spontaneous and direct observations are therefore challenging. Ebeko is an active volcano on Paramushir Island, northern Kuril Islands, showing characteristic Vulcanian-type activity. In 2019, we started a comprehensive survey using a combination of field station records and repeated unoccupied aircraft system (UAS) surveys to describe the geomorphological features of the edifice and its evolution during ongoing activity. Seismic data revealed the activity of the volcano and were complemented by monitoring cameras, showing a mean explosion interval of $34 \mathrm{~min}$. Digital terrain data generated from UAS quadcopter photographs allowed for the identification of the dimensions of the craters, a structural architecture and the tephra deposition at $\mathrm{cm}$-scale resolution. The UAS was equipped with a thermal camera, which in combination with the terrain data, allowed it to identify fumaroles, volcano-tectonic structures and vents and generate a catalog of 282 thermal spots. The data provide details on a nested crater complex, aligned NNE-SSW, erupting on the northern rim of the former North Crater. Our catalog of thermal spots also follows a similar alignment on the edifice-scale and is also affected by topography on a local scale. This paper provides rare observations at Ebeko volcano and shows details on its Vulcanian eruption style, highlighting the relevance of structural and morphologic control for the geometry of craters and tephra fallout as well as for structurally controlled geothermal activity.
\end{abstract}

Keywords: Ebeko volcano; small unoccupied aircraft system (UAS), Vulcanian explosions; air fall deposits; infrared imaging; photogrammetry

\section{Introduction}

Eruptions, their craters and fissures are known to be strongly controlled by pre-existing structures, such as fracture networks [1]. Crustal structures also play an important role during the initiation and lifespan of volcanoes, possibly affecting the locations of magma pathways, hydrothermal fluids and their alteration [2-5]. The effects of existing crustal structures are identified at the surface, as the morphology of volcanoes evolves in close association with this structural forcing. Also the deposition and erosion of material is controlled by conduit geometry, crater morphology and other structural consequences [6,7].

As deposition of eruptive material often obscures direct views of the underlying structures, general morphological expressions can be indirectly assessed where aligned vents and craters indicate underlying zones of structural weakness [8]. Craters may form in groups and alignments [9], developing 
into crater rows linked to dikes [10] or multiple vents along active and elongated fracture zones [11]. Volcano craters that are controlled by tectonic stress fields and preexisting crustal fault structures are also affected in terms of their geometry, stability and breaching direction [12], highlighting the importance of investigating these possible interactions.

Pre-existing structures not only control volcanism, but also strongly affect hydrothermal venting sites, as demonstrated by recent work [13-16]. The scales under consideration are important, where structural control is dominant over a large edifice scale but obscured at smaller scales [15]. Variations in permeability are thought to be the main effect of earlier structures, which together with lithology leads to the rather complex appearance of volcanic and geothermal fields. In addition, evolving stress fields may affect sites of fluid migration, volcanism and fumaroles $[13,17,18]$. To better understand the factors controlling the surface expression of volcanic activity, the spatial distribution of vents and thermal spots can be important parameters, which can be identified by direct and remote measurements.

The spatial distribution of escaping fluids and their pathways and structures can be assessed by visual and thermal aerial photography [19-21]. In addition, zones of hydrothermal alteration associated with thermal fluid escape are detected by airborne surveys [22]. These studies show that the detailed spatial observations and mapping of the fumaroles may provide a detailed picture of the processes of magmatic and fluid migration at active volcanoes. At many volcanoes, it is still challenging to gather such information; however, frequent and powerful explosions limit access and can obscure structures.

Unoccupied aircraft systems (UASs) can support observations and monitoring at hazardous volcanoes, aid in mapping volcanic structures and the quantification of geomorphologic changes, as well as identify hydrothermal processes [23]. UASs have a number of advantages compared to standard airborne photogrammetric surveys and satellite imagery, as they are low cost, allow generating very high resolution maps and are temporally flexible. Therefore, the use of UAS became a powerful tool in volcanology [23,24], as it allowed the estimation of eruption volumes [25], the detection of small topographic changes and fractures [5], sampling and gas measurements [26,27], the monitoring of deformation [28] and could even reach remote sites at distances exceeding the $100 \mathrm{~km}$ range [29]; moreover it could be used for many other volcanologic purposes [23-25]. Especially at explosive volcanoes, the use of a UAS is often the only affordable way to obtain samples and high-resolution terrain models, as vividly demonstrated for the Agung crisis [30] and steam-driven explosion structures at Merapi volcano, Indonesia [31], topographic changes at the flanks of Colima, Mexico [32] and the rapid growth and collapse at the dome of Santiaguito [28] and Fuego, Guatemala [33].

UASs are especially useful for structural assessments, allowing the study of the appearance, formation, geomorphology and dynamics of volcano craters and crater lakes at unprecedented resolution [18,23,24,31,34]. The quality of UAS-derived photogrammetric products [23] offers the possibility of low cost and repeated overflights and monitoring at volcanic craters even during eruptive activity [35], identification of structures, fissures and faults $[5,36]$ and the measurement of structures and fall deposits at craters [37]. Therefore, at Ebeko volcano, we gathered such photogrammetric data in an attempt to better understand eruption sites and the locations of fluid escape. Ebeko is otherwise difficult to access and frequent explosions have further increased since 2016 and put conventional aircrafts and operators at risk.

\section{Geologic Setting}

Ebeko is a composite cone located on Paramushir Island in the Kurile Islands arc, where the Pacific Plate subducts under the Okhotsk Plate [38,39]. Ebeko is located only $7 \mathrm{~km}$ WNW from the town of Severo-Kurilsk and $320 \mathrm{~km}$ SW of Petropavlovsk. The volcano is a source of hazards to daily hikers and the nearby town, producing air falls, poisonous gases and lahars [40-42].

Geologic reconstruction showed that the volcano's activity initiated in the Holocene over strongly eroded basement rocks of the Vernadsky Ridge [43], which is a tectonically active zone hosting a number of fissures, NNE-SSW oriented lineaments and chains of craters [40,44] (Figure 1). The majority of erupted products are andesites and basaltic andesites [45] that appear highly porphyritic with 
2-pyroxenes. The morphology of Ebeko reaches $1142 \mathrm{~m}$ above sea level (as we measured by GNSS), yet the active cones are only approximately $250 \mathrm{~m}$ high [40]. The active crater chain of Ebeko (Figure 1d,f) hosts three main craters referred to as the South Crater, Middle Crater and North Crater, with temporally varying cold and hot lakes indicative of a shallow groundwater level and interaction with the geothermal system [46]. Relatively strong eruptions of the Vulcanian type occur episodically, with an activity that appears to migrate along the NNE-SSW Vernadsky Ridge, such as eruptions in 1934-35, 1965, 2011 and 2016-2017 that occurred from the Middle Crater and in 1967-1971, 1987-1991, 2009-2010, 2016-20 from the North Crater and a deep funnel on its northeastern rim [41,47,48]. Sometimes eruptions have even occurred simultaneously at different craters. Starting in April 2018, the eruptions in the active funnel in the North Crater migrated to form a new crater located further westward, which is currently the only active New North Crater. Volcano-tectonic processes, degassing and an increased geothermal gradient are relevant on land and also continue to occur offshore, as inferred from seismic reflection profiles [49].
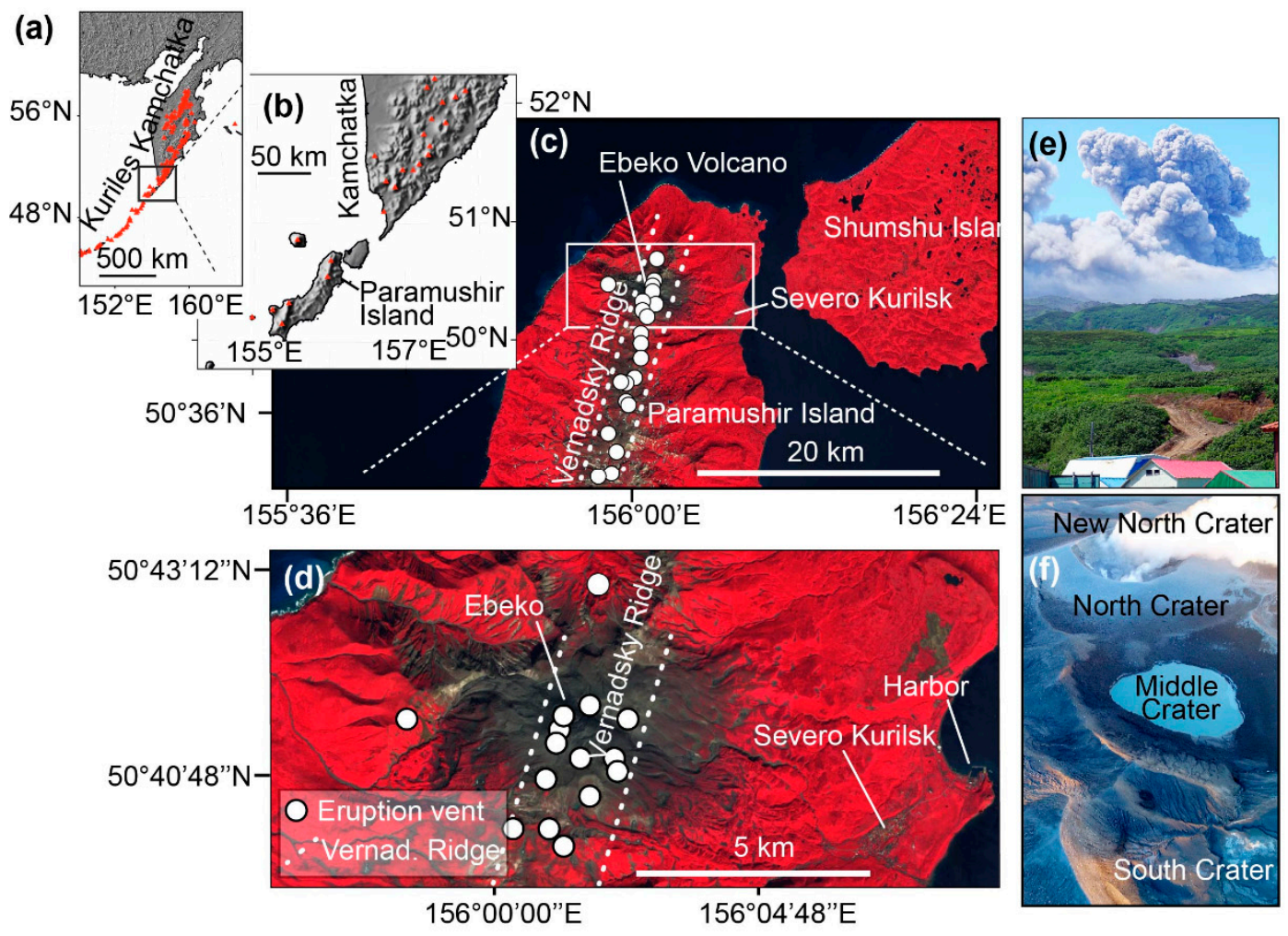

Figure 1. (a) Location map in northern Kuriles. (b) Southern Kamchatka and Paramushir Island, with Ebeko volcano being the northernmost volcano on the island. (c) Satellite color infrared (Sentinel-2 bands 8,4,3 from 13 September 2017) showing vegetation in red and bare soils and volcanic deposits in gray. The Vernadsky Ridge (white dotted line) is defined by fissures and cone alignments (relevant cones and crater vents are indicated by white circle symbology). (d) Close-up of Ebeko volcano, with a distance to the town of Severo-Kurilsk of only $7 \mathrm{~km}$. (e) Eruption at Ebeko as seen from Severo-Kurilsk on 11 July 2019 and (f) UAS view on 14 July 2019 showing the three craters aligned NNE-SSW, with the current eruptions in the New North Crater, a cold lake in the Middle Crater and fumaroles in the South Crater.

Ebeko volcano is renowned for its intense fumarolic activity and picturesque sulfur towers that cluster in four main fields $[41,46]$, which is also why most previous studies considered the geochemistry and petrology of the volcano, its hydrothermal system and associated alteration products [50,51]. Gas measurements by mobile DOAS systems reveal that $90 \%$ of $\mathrm{SO}_{2}$ emissions (approximately $100 \mathrm{t} / \mathrm{d}$ ) escape from the active North Crater and only $10 \%$ or less escape from other fumarole fields [52], 
suggesting that fluid pathways are channelized by the active conduit system, although the numbers may significantly increase during active periods to an $\mathrm{SO}_{2}$ flux of over $200 \mathrm{t} / \mathrm{d}$ [53]. Selected fumarole fields have been intensely studied, with some showing temperatures exceeding $500{ }^{\circ} \mathrm{C}$ [53] and others with conical subterranean structures that connect the fumarole fields at the surface with hydrothermal reservoirs at a depth of $10 \mathrm{~m}$ [54] or even 20-40 $\mathrm{m}$ [42]. The sites of fumaroles are known to appear and disappear or migrate laterally, sometimes (as in 1983) with the activity shifting by $200 \mathrm{~m}$ or more [40]; however, a systematic mapping of the fumarole fields, the crater morphology and fluid pathways has not been conducted yet.

Instrumental and permanent monitoring is very sparse. In 2019, there was one time lapse camera and one seismic station located in western Severo-Kurilsk town at a distance of $7.2 \mathrm{~km}$ from the volcano. High levels of natural and artificial noise do not permit the registration of weak seismic activity and the identification of volcanic explosions on seismograms is possible in only a few cases. Previously (in the Soviet Union era), frequent gas sampling was performed by the Institute of Volcanology [40]. Previous studies used thermal survey data and geochemical analysis for precursory and eruption activity assessments [40], which is why modern drone-based and geophysical records will also provide an important basis for robust assessment of the changes at this volcano. Sporadic field surveys allow for the sampling of temperature, gas and water at sites of fluid expulsion $[55,56]$ before the new eruption episode started in October 2016. A modern and comprehensive geophysical characterization of this new activity has not yet been achieved.

\section{Data and Methods}

We conducted a 10-day field campaign in July 2019 , with daily trips from a base camp $\left(156.0605^{\circ} \mathrm{E}\right.$, $50.6883^{\circ} \mathrm{N}, 700 \mathrm{~m}$ ) during which we installed a geophone seismometer, as well as time lapse cameras to record and count the duration of explosions, wind drift and the height of explosions, airfall and associated columns. We conducted repeated UAS overflights on two days with low wind and clear atmosphere conditions. As the UAS carried visual and infrared cameras, the data revealed detailed views of the ground and interior of the crater associated with a major explosion.

\subsection{Remote Sensing by an Unoccupied Aircraft System (UAS)}

UAS surveys were attempted on several days but were only successful on 14 and 15 July 2019 due to clear sky and low wind conditions. The 14 July flights were recorded immediately before and after one of the largest explosions. The 15 July flights were achieved for general mapping purposes and acquiring a dense image overlap for referencing.

UASs were Phantom 4 pro consumer drones equipped with a 20 MPixel optical camera $(5472 \times 3078$ pixels) and a $35 \mathrm{~mm}$ focal of 24 , set to record images at $0.5 \mathrm{~s}$ intervals. The launch site of all UAS flights was at the highest point of Ebeko volcano at $1142 \mathrm{~m}$ above sea level (a.s.l.) at $\mathrm{E} 156.0160^{\circ} \mathrm{N} 50.6859^{\circ}$. The flight height of the surveys was then $300 \mathrm{~m}$ above this launchpad at $1442 \mathrm{~m}$ a.s.l. All flight paths were preplanned but controlled manually to quickly respond to volcanic explosions, ash fall and sudden wind gusts. The UAS also carried a home-built plate hosting a thermal infrared FLIR Tau2 $640 \times 512$ radiometric camera with a $13 \mathrm{~mm}$ lens, recording at wavebands between 7.5 and $13.5 \mu \mathrm{m}$, which was linked to a Teax frame grabber and a GPS geotagging system recording at an $8 \mathrm{~Hz}$ interval. We defined the calibrated temperature range to $0-500^{\circ} \mathrm{C}$ because it was assumed that this range would cover the expected apparent temperature field at Ebeko volcano.

Thermal data depend on various object and environmental properties, which here are mainly the emissivity of the object, the distance, solar reflection, viewing angle and the presence of particles/gases in the electromagnetic radiation path [57] and these properties need to be considered to improve the results [58]. In this study, we assumed a constant emissivity of 0.95 , which is typical for volcanic environments [59] and a constant flight height (300 m). Other environmental effects that may influence the derived temperature, such as atmospheric attenuation, were considered using the radiometric 
correction theme in ThermoViewer software (Teax Technology, vs. 1.3.13), a transmissivity of 0.7, an environmental and path temperature of $10{ }^{\circ} \mathrm{C}$ and a humidity of $50 \%$.

In total, we recorded 4800 RGB images using the optical UAS camera and 11,300 thermal infrared images using the FLIR camera, all in the nadir field of view. The image data set was manually controlled for artifacts and cleaned. The thermal image data set was preprocessed in ThermoViewer software and exported in radiometric jpeg form.

We processed all the UAS photogrammetric data (both optical and thermal infrared) using the Structure-from-Motion (SfM) computer vision approach [60]. Using Agisoft Metashape (vs. 1.5.2) software, we achieved point cloud reconstruction on optical and thermal data chunks to reconstruct the three-dimensional morphology, structure and temperature field of the Ebeko volcano summit. Geoinformatics analysis was then performed in ArcGIS (vs. 10.2.1), where we investigated the morphology, identified thermal spots and measured the dimensions and changes in the optical and infrared dataset.

Due to the difficult and hazardous terrain, it was impractical to implement a ground control point (GCP) network and to create reliable georeferencing. The onboard GNSS geotagging that was used was yielding SfM products assumed to be consistent in the within-model horizontal distance measurement errors $(0.2-0.3 \mathrm{~m})$ being approximately one order of magnitude lower than the positional error [61]. We associated all models with respect to the best and largest UAS dataset acquired on 14 July 2019 (18:00-18:30 UTC) for accurate and consistent georeferencing by point matching the models. This reference model was based on 900 selected high-quality nadir photographs, yielding 39,000 tie points and a dense cloud consisting of 81 million points used to generate a $19 \mathrm{~cm}$ digital elevation model and a $9.8 \mathrm{~cm}$ orthomosaic with a total error of $1.9 \mathrm{~m}$. The UAS flights conducted just before and after the explosion were shorter and covered the active crater region only but were conducted at the same heights (300 m above the launch pad), yielding 12,000 tie points, 55 million dense points, DEMs of 20 $\mathrm{cm}$ and orthomosaics of $10 \mathrm{~cm}$, respectively. The dataset was compared against the reference dataset, which yielded relative errors that had an RMS of $0.3 \mathrm{~m}$ for the optical dataset and $0.5 \mathrm{~m}$ for the thermal datasets used in this study.

\subsection{Seismic Observations}

As a seismic unit, we used a $4.5 \mathrm{~Hz}$ three-component geophone (3D Geophone PE-6/B manufactured by SENSOR Nederland). A single unit was taken with us in the field at a location $\left(156.023057^{\circ} \mathrm{E}\right.$, $\left.50.694460^{\circ} \mathrm{N}, 1028 \mathrm{~m}\right)$ very close $(600 \mathrm{~m})$ to the center of the active North Crater and was used to identify explosive events. The geophone instrument was buried at $1 \mathrm{~m}$ depth, fixed in the ground using three steel spikes and covered by a plastic lid and then by tephra material for insulation. As a data logger, we used a DSS CUBE recorder to save the data with a sampling frequency of $50 \mathrm{~Hz}$ and internal batteries as a power supply, as well as a built-in GPS for accurate clock synchronization.

The data were analyzed using the Python package Pyrocko and the Snuffler toolbox [62] to show the waveforms, perform event picking and investigate the spectral density associated with the explosive activity. We bandpassed the data (highpass 0.2 , lowpass $2 \mathrm{~Hz}$ ) and first visually compared alleged explosion events to camera data. Based on this, we define an STA/LTA picker. Short events associated with small rockfalls or earthquakes were not further considered in this study. For spectrogram generation, we considered a window length of $100 \mathrm{~s}$, overlapping 75\%, with the Hamming taper function, to produce daily plots, allowing us to obtain an overview of the occurrence of explosions. All timings are given in UTC (local time is UTC+11).

\subsection{Time-Lapse Camera Observations}

We installed time lapse cameras to remotely record the occurrence of explosions, determine wind drift during the explosions and help interpret the other data, such as to distinguish between explosions and outgassing events in the seismic records. 
The cameras we used were Reconyx UltraFire trail cameras, which were set to record images every $15 \mathrm{~s}$ at a resolution of $2304 \times 1296$ pixels, $72 \mathrm{dpi}$. The $5 \mathrm{~mm}$ lens has a full frame equivalent focal length of $37 \mathrm{~mm}$. Internal lithium batteries powered the cameras. The time-lapse cameras have no internal GPS clock, which we controlled by synchronization to a GNSS station before the installation and controlled again at the end of the experiment for possible time drift (which were all found to be below the sampling interval and therefore considered nonsignificant). We placed three cameras on small tripods, one camera on the South Crater rim close to the UAS launchpad $\left(156.0137^{\circ} \mathrm{E}, 50.6852^{\circ} \mathrm{N}\right.$, $1130 \mathrm{~m}$ ) and the other two other to the east of the active crater, which were frequently covered by ash, which is why we concentrate our analysis on the South Crater rim camera. The camera data were then analyzed using kymograph recording $[63,64]$, which is a sophisticated method of photo sequence analysis. We perform this analysis by considering time lapse camera image data stacks and by choosing a vertical line through the active crater in all images (2880 images in a 12-hr interval) and plotting the RGB pixel values of this line along a time axis. The kymograph is therefore a time-space plot that allows us to quickly identify the occurrence, height and duration of explosions as seen in the camera images (Figure 2).

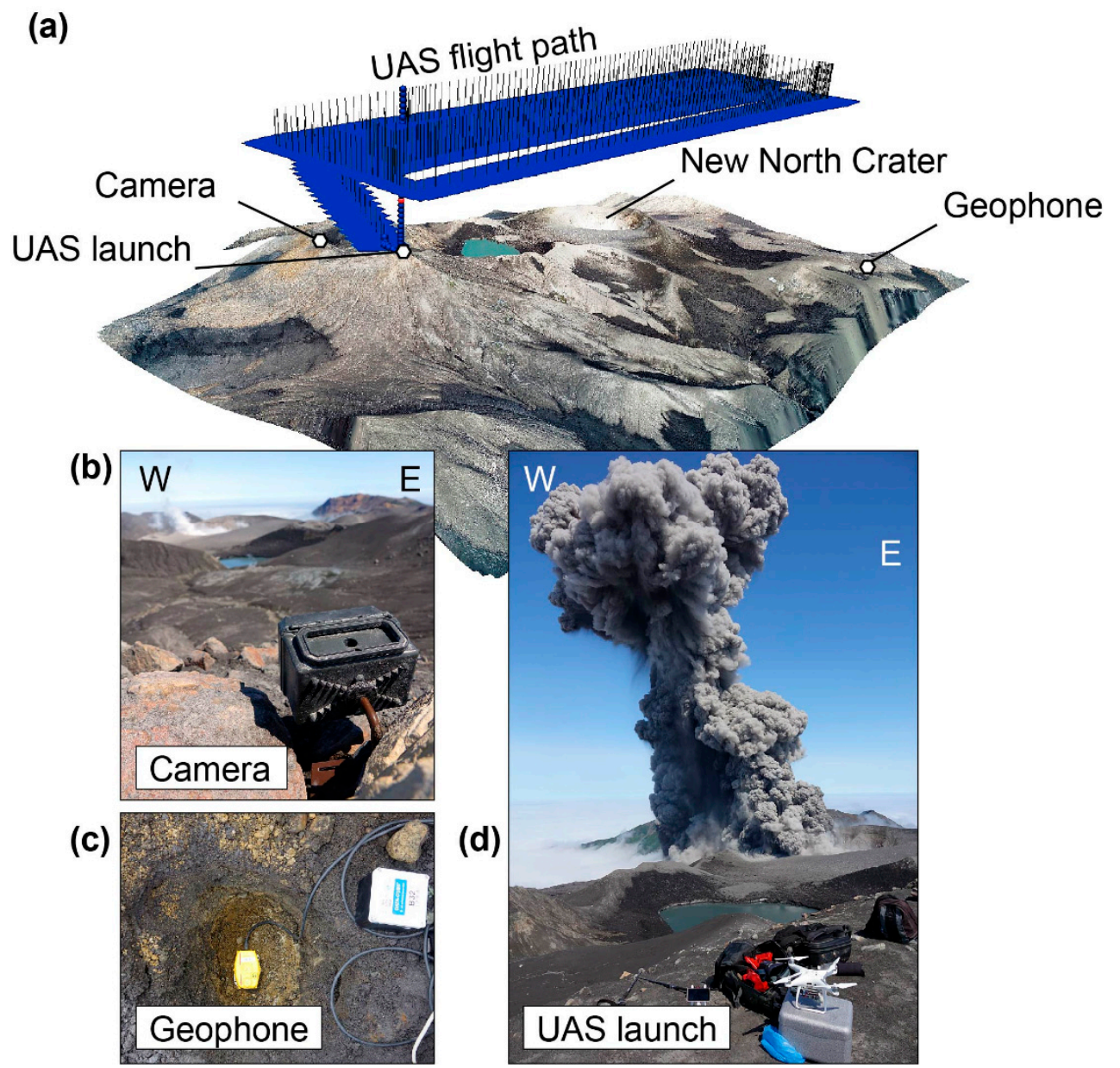

Figure 2. Field deployment (a) perspective map view of the active Ebeko crater, location of the camera and the geophone seismic station. The unoccupied aircraft system (UAS) launch site and flight path (indicated by blue cameras) are shown. (b) Time lapse camera looking northward to the active New North Crater (steaming in background) and (c) geophone (yellow) installed and buried at $1 \mathrm{~m}$ depth recorded by a DSS data cube (right). (d) The UAS launch site and explosion at the active crater on 2019-07-13 at 23:40 UTC. 


\section{Results}

The results are presented in two parts. First, we present the general morphology and structural analysis together with thermal spot density distribution. Second, we describe the records associated with a major explosion.

\subsection{General Geomorphology and Structural Analysis}

The $\sim 9.8 \mathrm{~cm}$ resolution orthomosaic reveals details of the structures and, in comparison to the $19 \mathrm{~cm}$ DEM, a detailed geomorphological database (Figure 3). We clearly distinguish the three main craters (the South Crater, Middle Crater hosting a lake and North Crater) and the small new crater in the north referred to as the New North Crater, with areas of $42,58,80$ and $21 \times 10^{\wedge} 3 \mathrm{~m}^{2}$, respectively. The main craters are aligned NNE-SSW at an azimuth of $\mathrm{N} 14^{\circ} \mathrm{E}$ with very regular spacing; the centers of the South and Middle Craters are $236 \mathrm{~m}$ apart and those of the Middle and North Crater are $239 \mathrm{~m}$ apart. The center of the New North Crater is $110 \mathrm{~m}$ away from the center of the North Crater. As the crater morphologies overlap, their assemblage is nested, defining an elongated NNE-SSW-oriented crater depression (Figure 3a). The diameters of the South, Middle and North Craters in the W-E direction are $284 \mathrm{~m}, 270 \mathrm{~m}$ and $304 \mathrm{~m}$, respectively. The new and active crater (the New North Crater) located in the north of the North Crater has a W-E diameter of $211 \mathrm{~m}$. The rim of this new crater is lower on the southern side (1090 $\mathrm{m}$ a.s.1.) than on the west (1102 m), north (1105 $\mathrm{m})$ and east (1115 $\mathrm{m})$. The inner walls are steep on the north side with slopes exceeding $60^{\circ}$ and gentle on the southern side, generally elongated from E-W (211 m E-W versus/165 m N-S, aspect ratio 1.28). The deepest point in the New North Crater is at $1045 \mathrm{~m}$, meaning that the maximum depth of the crater is approximately $70 \mathrm{~m}$. Therefore, the floor of the New North Crater is lower than the elevation of the North Crater (1085 $\mathrm{m}$ a.s.1.), lower than the lake level of the Middle Crater $(1078 \mathrm{~m})$ and below the elevation of the South Crater $(1124 \mathrm{~m})$. A large number of bombs and bomb sags can be seen surrounding the active crater (Figure $3 \mathrm{a}$ and Figure 6) but are also found at distances greater than $500 \mathrm{~m}$. Some small subsidence pits also formed due to ash-covered snow melting above fumaroles and sites of former lakes (sp in Figure 3), as seen on the western rim of the North Crater or $200 \mathrm{~m}$ to the northeast of the active crater (Figure $3 b$ ).

The orthomosaic of the thermal camera images reveals the largest anomaly inside the New North Crater, with apparent temperatures reaching $220^{\circ} \mathrm{C}$. We note that this temperature is likely damped by steaming of the crater seen in simultaneous optical images (compare Figure 3a,c). The Middle Crater is not expressed by high temperature and represents the coldest region. Temperature anomalies are found inside the South Crater at two main zones, each with a diameter 50-120 m, but also on the crater flanks (Figure 3i). In addition, we identify a large number of moderate temperature anomalies exceeding 50 ${ }^{\circ} \mathrm{C}$ on the eastern flank of Ebeko volcano, following the dominant NNE-SSW alignment (Figure 3f). Some of these temperature anomalies have dimensions exceeding $50 \mathrm{~m}$ in diameter, representing distinct fumarole fields.

Close comparison of aerial photos, digital terrain models and infrared images allows mapping of the fumaroles, thermal springs and other hot points. We distinguish 282 thermal spots, identified as localized thermal spots surrounded by a cold region. These thermal spots are clustered in four main fields, which are 36 spots in the New North Crater (Figure 3b), 42 spots in the South Crater (Figure 3b,h) and 118 spots on the east flank at the locations of fumaroles and sulfur towers (Figure 3f). The thermal spots identified in the New North Crater reveal the highest temperatures; therefore, the small number of identified spots might be misleading. In addition, we find some isolated anomalies, such as those temporarily exposed in the thick snow cover to the east of the lake-infilled Middle Crater or at the sites of large bombs surrounding the active crater. Locations outside the active craters and the E-flank are rare, with less than $8 \%$ of all thermal spots identified. 

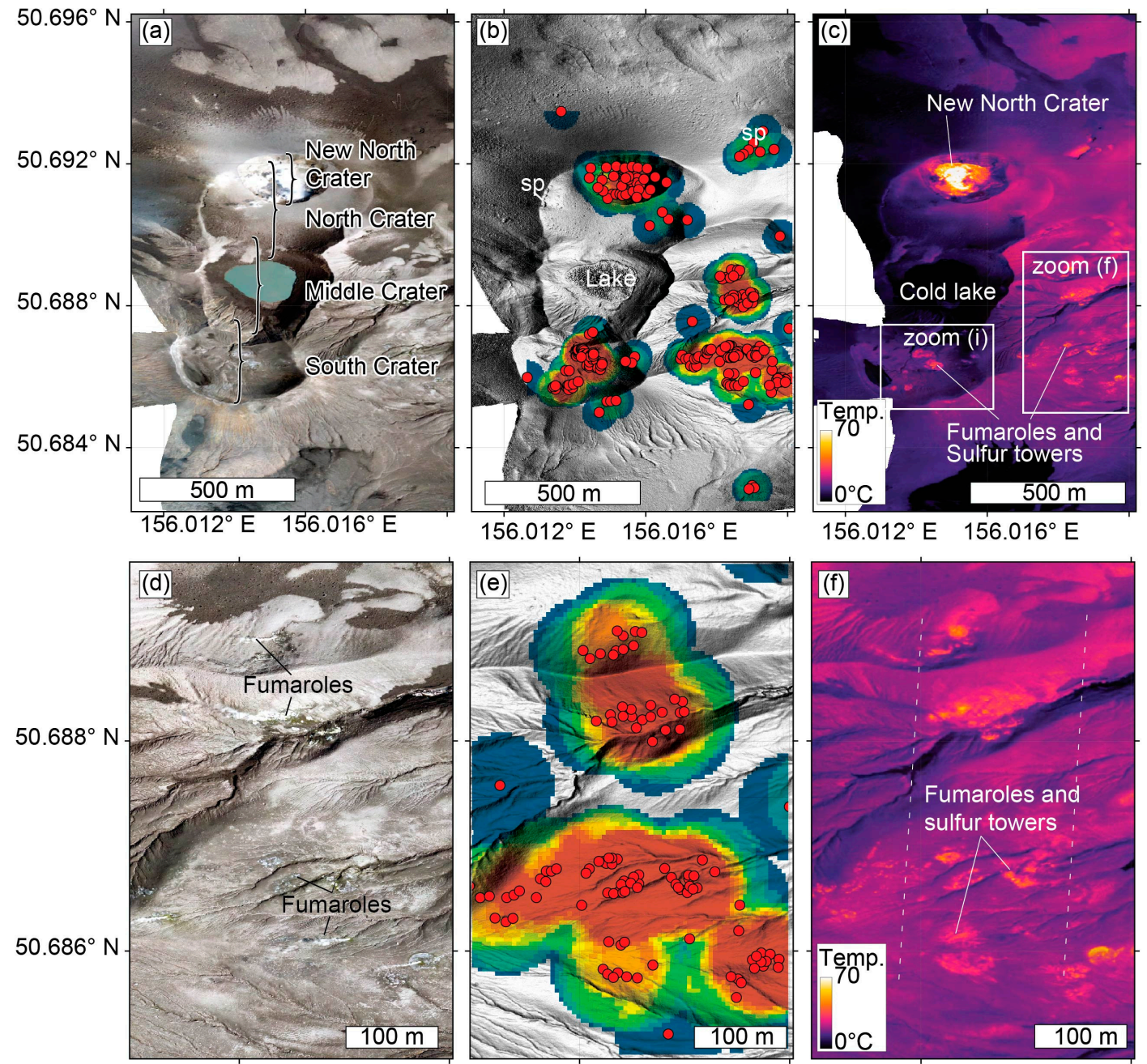

$156.018^{\circ} \mathrm{E}$

$156.018^{\circ} \mathrm{E}$

$156.018^{\circ} \mathrm{E} \quad 156.02^{\circ} \mathrm{E}$
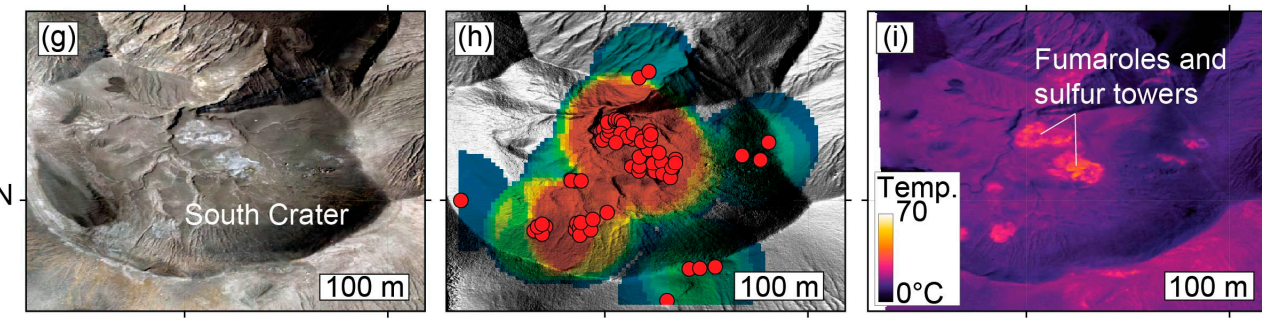

$156.014^{\circ} \mathrm{E} \quad 156.016^{\circ} \mathrm{E}$

$156.014^{\circ} \mathrm{E}$

$156.016^{\circ} \mathrm{E}$

$156.014^{\circ} \mathrm{E} \quad 156.016^{\circ} \mathrm{E}$

Figure 3. Results from the UAS survey. (a) Orthophoto generated from optical UAS camera data using the Structure from Motion (SfM) approach. (b) Thermal spots associated with hot springs and fumaroles identified from thermal cameras and optical data (shown by red dots) and cluster analysis (red shades indicate high clustering density) overlapped on a shaded relief digital terrain model generated from the optical UAS data. sp-subsidence pits. (c) Thermal infrared orthophoto. White boxes show close-ups as illustrated in the center and lowest row of the figure. Note that thermal spots cluster in fields, with a local alignment associated with ravine and ridge topography (panel e). Thermal spots are also located at sites of former eruption vents, as in the South Crater (panel i).

\subsection{Explosions Observed by Instrumental Network, Geomorphology and Structural Analysis}

The instrumental network provided important data for contextualization of the remote sensing observations from UAS data. Explosions exclusively occurred in the New North Crater and no activity was observed in the other craters. Our camera allowed for the visualization of the occurrence, wind drift and scale of the explosions. 
The comparison of the camera kymograph with the seismic spectrogram reveals a very good agreement of the retrieved event information during clear sky conditions (Figure 4), with 34 events during daytime (black arrow symbology in Figure $4 \mathrm{~b}$ ). The seismometer allowed the counting of explosion events, which represented 192 events with durations over $5 \mathrm{~s}$, with an average of $34 \mathrm{~min}$ intervals between the eruptions for the entire measurement period of 10-14 July 2019. However, a closer look at the records documents very uneven activity, as revealed on the clear sky day of 13 July 2019, when the camera kymograph allows for the confirmation of the occurrence of dark ash-laden clouds. In the first $6 \mathrm{~h}$ of daylight, only minor activity was associated with steaming and mild explosions, such as at 20:05 UTC (8:05 local time), drifting westwards. Then, eruptive activity strongly increased, with 11 major events in the second half of the day, the strongest identified by camera at 23:40, 1:15 and 8:29 UTC. The seismic data generally confirm this but also reveal a number of events in the $<10 \mathrm{~Hz}$ spectral frequency (although with smaller amplitudes and durations), associated with degassing pulses and white plumes, as observed by the cameras. The between-explosion activity is mainly related to degassing, as observed by the white steam plume escaping from the New North Crater. The strongest steaming occurs immediately after explosions, gradually decreasing until almost virtual absence before the next explosion is initiated. The maximum eruption heights cannot be deduced from the close camera location, but the seismic strength and duration of the signal concurs with the visual strength of the eruption, exceeding the image frame in height (which was set to $500 \mathrm{~m}$, Figure 3c).

\section{(a) Camera kymograph}

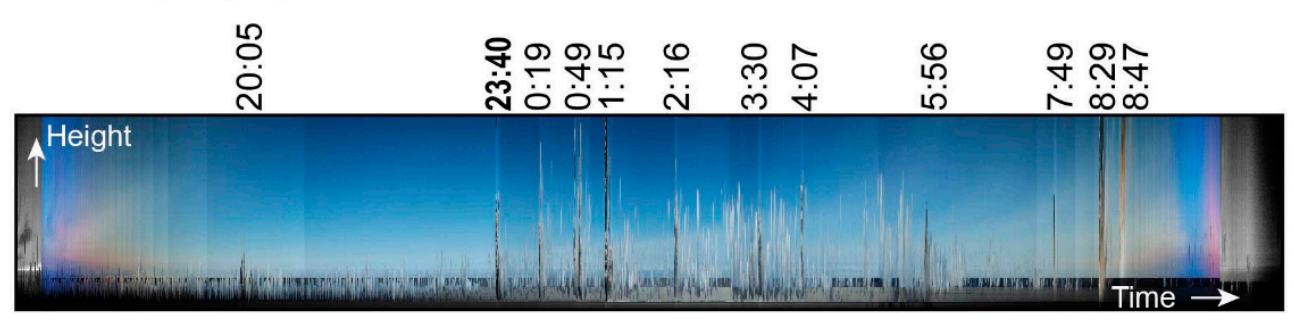

(b) Seismic spectrogram

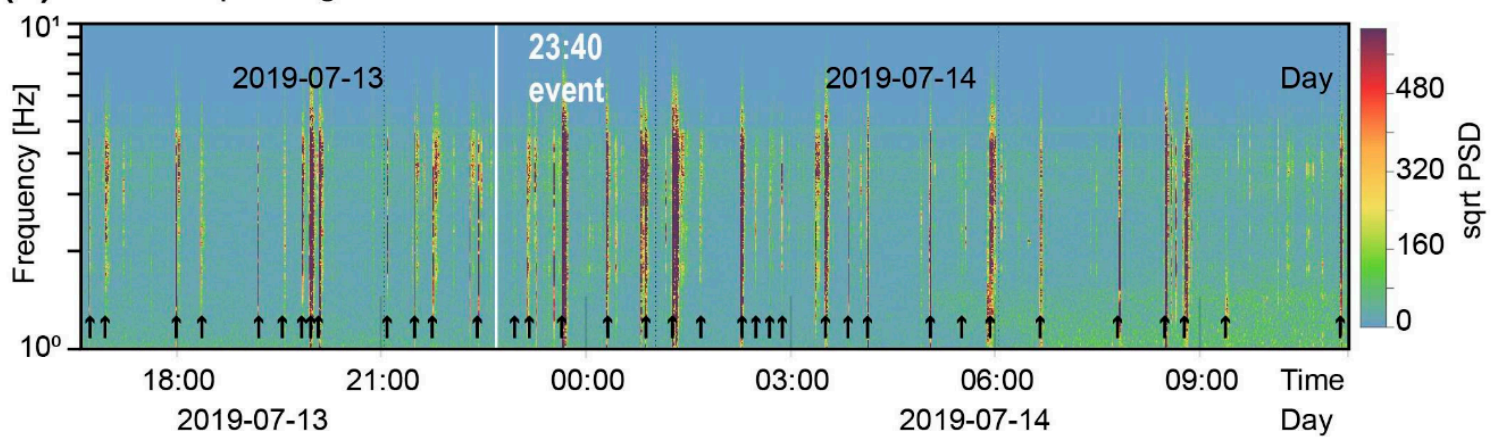

Figure 4. Instrumental records. (a) Camera kymograph generated by the vertical RGB line (y-axis) versus time ( $x$-axis) shows 12 main eruptions on one day (dusk to dawn on 2018-07-13 to 2018-07-14 UTC). The first large event after $>3$-h of quiescence occurred at 23:40. (b) Spectrogram generated for seismic station show clear explosion occurrences (dark vertical lines). The events picked using the LTA-STA trigger are indicated by small black arrows. Eruption at 23:40 monitored closely by the UAS is highlighted by white timing. Note that the occurrence of eruption multiplets (at 20:06 and 8:29) was preceded and followed by pronounced lag times.

We investigate the 23:40 eruption in further detail (Figure 5). The camera data show an eruption cloud initiating at 23:39:45, exceeding $200 \mathrm{~m} 15 \mathrm{~s}$ later, drifting westward and reaching a height of $400 \mathrm{~m}$ at 23:40:15 and above $500 \mathrm{~m}$ (which is the image limit) at 23:40:45 UTC. The eruption lasted at least $2 \mathrm{~min}$, which was also confirmed in the seismic data (Figure 5). In fact, the seismogram suggests 
that the eruption initiates rapidly, possibly in two pulses, with a power spectral density peak at $4 \mathrm{~Hz}$. The spectrogram reveals a $>10 \mathrm{~Hz}$ frequency lasting $160 \mathrm{~s}$ and a much longer and lower frequency of $<$ $10 \mathrm{~Hz}$ lasting approximately $420 \mathrm{~s}$. The comparison of optical and seismic data suggests that the higher frequency is dominated during explosions, followed by a $<10 \mathrm{~Hz}$ frequency signal tail associated with gas jets and steaming activity.

(a) Seismogram of 23:40 eruption

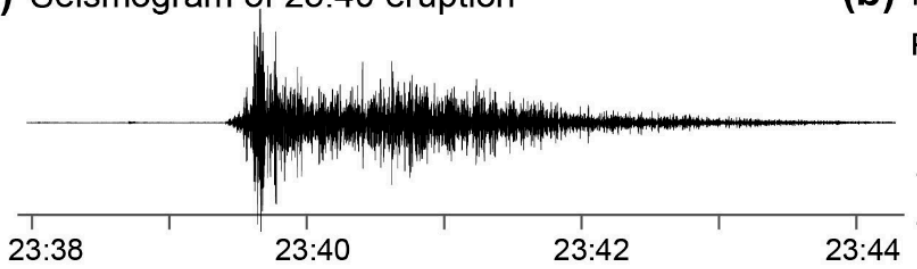

(c) Spectrogram of $23: 40$ eruption (b) Power spectral density

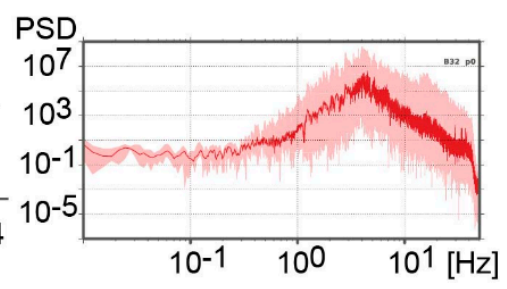

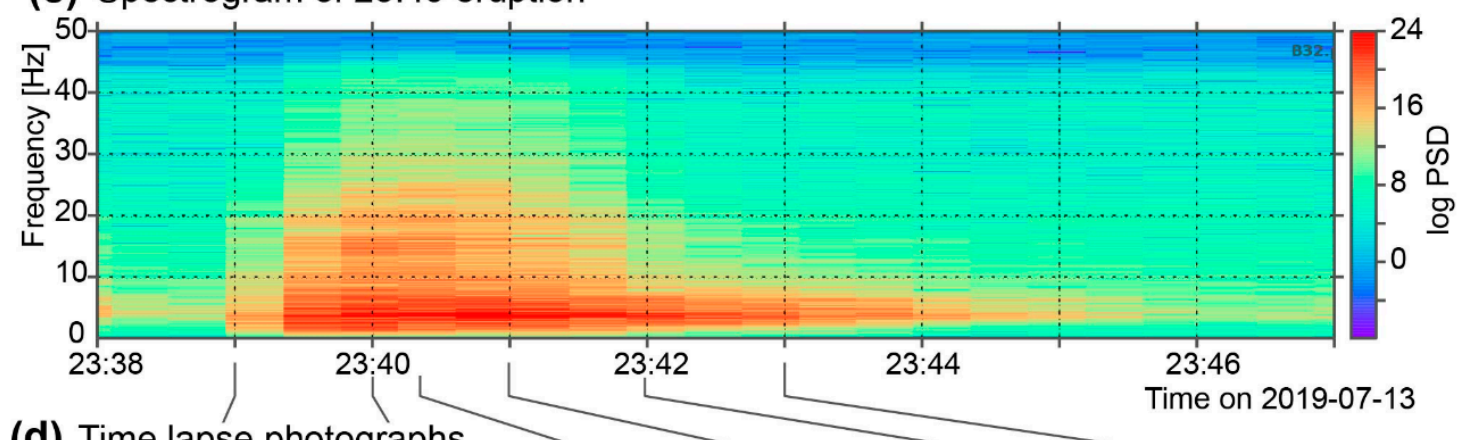

(d) Time lapse photographs

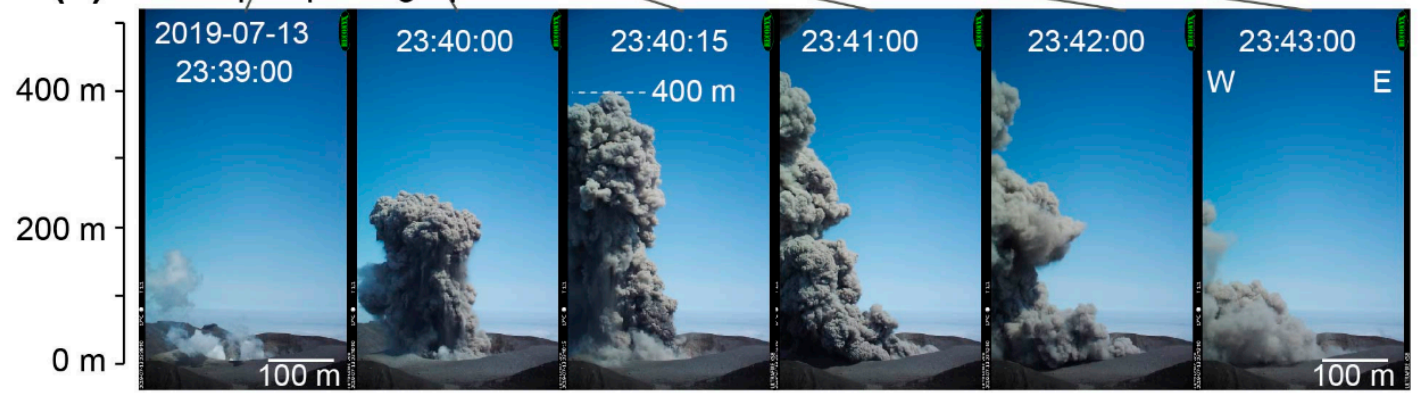

Figure 5. Geophone seismic records (radial component, E-W) and camera documentation of the 23:40 eruption event on 13 July 2019. (a) Seismogram of the 23:40 event, revealing a rapid emergence, two main amplitude peaks and a long coda. (b) The Power Spectral Density (PSD) indicates a peak at 3-4 Hz. (c) The spectrogram reveals a dominant lower frequency but also a 2-min lasting $10-40 \mathrm{~Hz}$ frequency episode associated with bomb and rock falls. (d) Photographs of the 23:40 event. Eruption height exceeded $400 \mathrm{~m}$, airfall towards the west (left in north-looking camera view).

UAS flights conducted in the $20 \mathrm{~min}$ immediately before and after the 23:40 eruption indicate important changes (Figure 6) inside and surrounding the active crater. A comparison of apparent temperature fields reveals that before the explosion, the outer flanks are cold and the inner crater is expressed by apparent temperatures mainly between 120 and $160{ }^{\circ} \mathrm{C}$ (Figure 6a,d). The flight conducted immediately after the explosions shows a pronounced deposition field $81,200 \mathrm{~m}^{2}$ in size, marked by elevated temperature on the outer NE flank of the active crater (Figure 6b), which is in agreement with the prevailing wind direction of $\mathrm{N} 70^{\circ} \mathrm{W}$. The temperature-derived deposition zone is composed of a large number of small and distinguishable particles, which were interpreted to be bombs and fine materials (Figure 6b). The temperature decreases with distance to the New North Crater, but the isolines of equal temperature show some pronounced complexities (Figure 6c). Temperature isolines show a strong morphological dependency, such as the inner part of the large North Crater being elevated in temperature (Figure 6c). The temperature field inside the active crater at this time 
is between 160 and $220{ }^{\circ} \mathrm{C}$ for most of the pixels and therefore strongly increased compared to the pre-eruption survey.

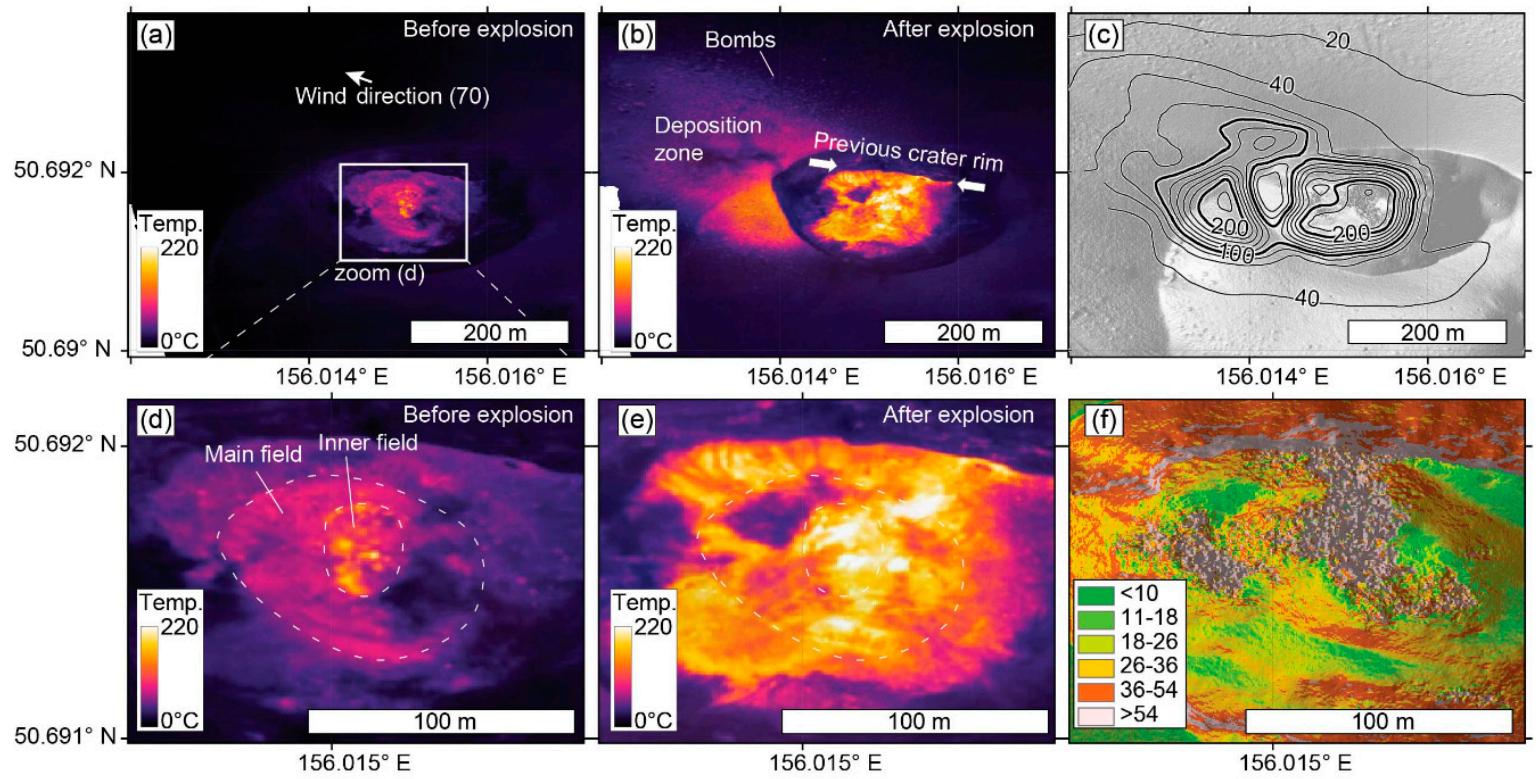

Figure 6. New North Crater before and after the 23:40 event on 13 July 2019 recorded by a UAS thermal camera. (a) Before the eruption, the thermal infrared orthomosaic shows main temperature zones. The enlarged crater area (panel $d$ ) is indicated by a white rectangle. Note that the data are the same as in Figure $3 \mathrm{c}$ but with different color scales to allow comparison to UAS data after the explosion. (b) After the eruption, the temperature increased inside the active crater but also on the western flank, indicating the deposition zone. Enlarged area (panel e). (c) Temperature isolines (interval $20^{\circ} \mathrm{C}$ ) derived from data shown in panel b. (d-f) Enlarged inner crater. (f) Slope map calculated by the gradient of the digital terrain model, revealing structures aligned along the previous crater rim.

Structural analysis reveals that a clear WNW-ESE temperature gradient is seen in the northern inner slope of the crater. This gradient can be better understood by considering the morphological scars that are oriented WNW-ESE, as shown in the slope map (Figure 6f), implying that the temperature field (and deposition of hot fresh material) is affected by morphology and/or by the fluid pathways changing at the rim of the previous North Crater where this New North Crater has evolved. An interesting finding is the zonation of the temperature fields inside the crater, revealing a generally elevated crater field, a main field with increased temperature and an inner field. The inner field is elongated in the NNE-SSW direction and therefore similar to the arrangements of the main craters and the alignment of temperature anomalies and thermal spots on the flank of Ebeko volcano.

\section{Discussion}

Ebeko volcano displays Vulcanian explosive activity at the northern edge of the North Crater, where a new 70-m deep explosive funnel has evolved. Using the UAS data, details of the geomorphology and structures of this New North Crater and its environment were mapped. The digital terrain model together with orthophotos and infrared imagery reveals that the crater formed on the northern continuation of a crater row aligned NNE-SSW and was strongly affected by other pre-existing structures as sketched in Figure 7. We compared the results to in situ geophysical observations and were able to determine (i) the general eruption frequency and NNE-SSW alignment of partially overlapping craters, (ii) the NNE-SSW alignment of temperature anomaly fields, (iii) the expression of $\sim 300$ thermal spots, (iv) the geometry of the newly formed crater and its inner temperature anomaly and (v) the deposition of new materials associated with a single explosion. These results are novel for the Ebeko site but may also help to better understand other volcanoes where access and structures are 
difficult to reach, highlighting the efficient use of UAS together with time lapse and geophone records for temporal monitoring. In the following, we first discuss the limitations and performance of our approaches and then elaborate on the structural control as well as the wider implications of this work.

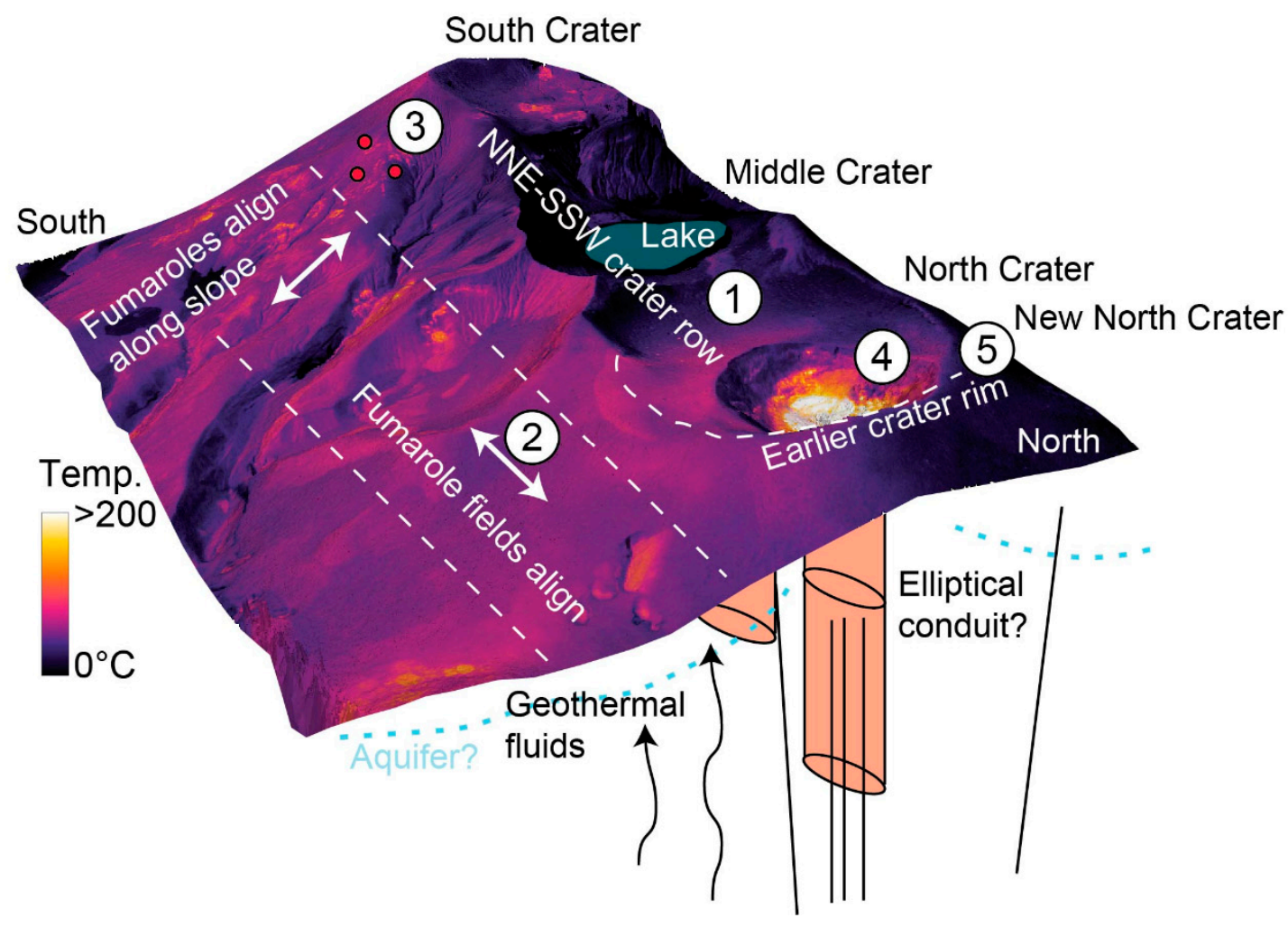

Figure 7. Synthesis of the structural architecture and analysis of this work highlighting the fluid pathways affected by inferred volcano-tectonic structures. Labels 1 to 5 describe (1) the general eruption frequency and NNE-SSW alignment of partially overlapping craters, (2) the NNE-SSW alignment of fumarole thermal fields obscured on smaller scales by morphology, (3) the expression of 300 thermal spots, (4) the elongation of the newly formed crater and its inner elliptical temperature anomaly possibly associated with an elliptical conduit and (5) the deposition of new materials. The presence of shallow reservoirs or an aquifer is based on earlier studies [42,54].

\subsection{Limitations and Performance}

While the instruments and analysis methods used provide the first detailed accounts of the new eruption episode at Ebeko volcano, a number of limitations are relevant to mention. Most of our analysis is based on UAS data. We used a simple consumer drone with a 30-min flight time, which, when carrying the FLIR Tau2 thermal infrared camera, was reduced to only 18-20 min. Therefore, even though multiple UAS flights were conducted, we could not monitor the initiation of an eruption inside the crater by UAS. Observation of the initiation of an eruption by UAS may shed some light on the surface expression of the conduit geometry. Our UAS flights were conducted before and after eruptions so that we could only approximately interpret the location and dimension of the surface expression of the conduit.

As the UAS flights were conducted during a very high activity phase of the volcano, with tephra and even decimeter-sized bombs found at distances exceeding $500 \mathrm{~m}$, we were not able to record ground control points (GCPs). This limitation comes with increased uncertainties of the absolute position and possible error and artifact propagation. We attempted to control this uncertainty by comparing the SfM point clouds against each other, but cannot rule out any systematic positioning errors. Moreover, the coverage by the UAS, although flying over the most relevant parts of the volcano, was not ideal, as the western flank and the surroundings could not be included in the analysis. This 
limitation was due to the rapidly changing wind conditions and fog/cloud formation, especially on the western flanks.

The thermal infrared UAS survey was conducted from a flight height of $300 \mathrm{~m}$ above the launch pad (1142 $\mathrm{m}$ a.s.l) so that the base of the New North Crater was seen in the UAS camera images from a distance of approximately $400 \mathrm{~m}$. Precise measurements of the apparent temperature strongly depend on distance to the target [65], so the true temperature may be underestimated by our measurements. Independent measurements at fumaroles suggest temperatures up to $490^{\circ} \mathrm{C}$ [52] or even exceeding 500 ${ }^{\circ} \mathrm{C}$ in the new explosive funnel in 2015 [53]. In addition, steaming activity may dampen the infrared signal and reduce the apparent temperature, while the strength of the method is that the structural analysis is less affected by such parameters $[18,28]$. We therefore note that the true temperature might be higher than the measured temperature, although the temperatures of only $160-220^{\circ} \mathrm{C}$ in the inner crater as measured immediately (within $\sim 20 \mathrm{~min}$ ) after an explosion were indeed surprising. While we cannot explain these low temperatures, we may speculate that (i) the eruptive products are indeed relatively low temperatures due to cooling by surface water (the crater floor is lower than the nearby cold water level in the maar-like Middle Crater), (ii) fine-grained (possibly remobilized) ash quickly covers the materials and dampens the temperature or (iii) our measurements are biased by measurement artifacts arising from small-scale thermal structures, large measurement distances and steaming effects.

The measurements performed using time lapse cameras and a single geophone instrument gave simple but highly useful information on eruption occurrence, wind drift and eruption strength. The instruments were properly working and were hence used for a first-order characterization of the eruption activity and intervals. The comparison of camera and seismic records indicated that none of the methods alone would have been complete, as we observed strong seismicity during periods of degassing (which by mistake could be interpreted as an explosion), as well as strong nearly horizontal westward drift of eruption plumes (which by mistake might have been missed by the cameras placed further east on the volcano slopes). As no other systematic measurements are accessible for the earlier activity episodes at Ebeko, we cannot compare our results to previous records.

\subsection{Structural Influence}

Using the UAS data, we identified approximately 300 thermal spots. Earlier volcanologic mapping was conducted based on aerial photography but dates back over 30 years (the most comprehensive photogrammetric survey was in 1988) and could distinguish between thermal areas and main fumaroles and pots of thermal waters, counting only 25 such sites [41]. As no thermal infrared camera was available during this time, the work relied on a combination of remote sensing and field validation. However, as previous researchers noted the migration of fumarole sites by as much as $200 \mathrm{~m}$ (as in 1983; [40]), our detailed and accessible maps provide a unique basis for further studies on the dynamics of thermal spots and fumaroles. Previous studies reveal that both magmatic and hydrothermal activity is migrating, appearing at one site while ceasing at another site, with possible systematic trends following the NNE-SSW structures.

The eruptive activity at Ebeko migrated back and forth along the NNE-SSW crater row, with explosions from the Middle Crater (1934-35, 1965, 2011 and 2016-2017) and from the North Crater (1967-1971, 1987-1991, 2009-2010, 2016-20) and some of the cases exhibited simultaneous explosions at both craters. In addition to the changing vent positions, a migration of individual fumaroles and thermal fields was also identified. One may therefore conjecture that fluid pathways seal and reopen, with systematics that on a large scale are strongly controlled by the hypothesized NNE-SSW fracture system. Furthermore, we found it puzzling why maar-like lakes occasionally developed along this system, either cold (as currently in the Middle Crater) or hot (as it was in 2005-2007 in the North Crater). Our findings suggest that both magmatic pathways and geothermal pathways are strongly structurally controlled by either fracture sets (e.g., the E-flank thermal field) and/or pre-existing vents (e.g., thermal field in the South Crater) as summarized in Figure 7. A cold water infill in the maar-like 
Middle Crater may indicate that thermal fluids are not rising there, which could be associated with a currently impermeable system. We may conjecture that the different magmatic and geothermal pathways are either competing with each other, where activity at one venting site causes a decrease in the other venting site or are temporally connected. It is possible that hydrothermal activity changes the permeability, as has been proposed at other locations [66], which may help us to understand the sealing of one vent and the reopening of the other vent. Eye-witness accounts during earlier explosions suggest that the activity occurred simultaneously from two opposing vents at the active funnel of the North Crater, which may support this hypothesis of temporally connected pathways.

Most of the identified thermal spots cluster in fields described earlier (e.g., [46,51,52,54,56]). These fields elongate along E-W ravines but also cluster in a NNE-SSW direction, similar to the arrangements of the nested craters (South, Middle, North Crater and New North crater). We identify a weakly expressed but clearly distinguished zone of thermal fields aligned on the eastern flank of Ebeko. This large-scale (edifice-scale) feature is not similarly seen on smaller scales. Considering any singular thermal field, the distribution of thermal spots appears to be affected by morphology and other local effects and are often aligned subparallel to erosional ravines and ridges, which are east-west on the eastern slope of Ebeko. This observation, a large-scale structural control obscured by morphology and ravines on a smaller scale, is in line with findings made elsewhere [15], highlighting the importance of the scales under consideration. In this view, structural control is dominant on a large edifice scale but obscured on smaller scales by morphology and other effects.

\subsection{Eruption Dynamics}

The eruption dynamics at Ebeko are characterized by Vulcanian eruptions [47] forming bread-crust bombs exceeding $5 \mathrm{~m}$ in diameter. Another recent study tested the performance of the atmospheric electric potential gradient, allowing monitoring of the passage of ash plumes over Severo-Kurilsk [67]. Using our seismic and camera records, we could not measure the far field drift but the occurrence of the explosions, as well as the associated near-field ash plume and effects. For the four-day period of 10-14 July 2019, we counted 192 events, yielding an average interval of 34 min between the onset of eruptions. We also note (see Section 4.2), however, a strong irregular activity. On 13 July 2019, in the first $6 \mathrm{~h}$ of daylight, only minor activity was associated with steaming and mild explosions, such as at 20:05 UTC (8:05 local time), strongly increasing later that day with 11 major events in the second half of the day (strongest 23:40, 1:15 and 8:29 UTC, respectively). We further find that eruptions often occur in clusters, with double or triple eruptions occurring within a few minutes only, followed by pronounced periods of quiescence. While our short data set and limited number of events do not warrant a more rigorous statistical testing of this idea, the repose gap and clustered explosions might be comparable to the behavior of other (Strombolian type) eruptions at volcanoes [68,69] and geysers [70]. The comparison to Strombolian and geyser explosions is particularly interesting, as the dynamics of Vulcanian-type eruptions also shows periodic behavior and recharge-time-dependent eruption size [71]. A similarity further exists in the presence of double or triple eruptions, i.e., eruptions occurring in very close succession followed by a long repose period (approximately $3 \mathrm{~h}$ in our dataset, see also Figure 3c). Therefore, one may speculate that the eruption dynamics at Ebeko are an example of Vulcanian style explosions that show an apparent irregularity modulated by explosions that occur in close succession. Whether this mechanism is controlled from a deep depth by rising fluids, at shallow depths or even at aquifer levels is difficult to ascertain from our available data.

\subsection{Eruption Deposition and Isopach Analysis}

Tephra deposition, in particular, may obscure the structural architecture of volcanoes, but is difficult to monitor and quantify in the field. Analysis of tephra allows us to derive important information on explosive eruptions and intensity and allows indirect assessment of eruption height and dynamics [72]; therefore, parameters on tephra depositions and thickness are critical for the assessment of related volcano hazards [73,74]. In particular, information on the dispersion and distribution of 
tephra surrounding explosive vents is essential for understanding the volcano [75]; however, data are commonly limited due to poor preservation and lack of access to the deposition zones. As pointed out earlier [76], both the proximal and distal locations are challenging to elaborate in the field, despite the relevance for understanding those deposits. In particular, the proximal region of deposition is complex due to local plume and topographic effects. Characterization of the gradient of deposit thickness and clast size is affected by subjectivity and has remained challenging and rarely preserved due to post-eruption processes, which is why traditional isopach reconstructions are associated with major uncertainties and subjective decisions [77]. Accurate field assessments are highly relevant for developing improved modeling and forecasting techniques [74,76]. As we show, the UAS data may be used for tephra deposit isopach mapping and together with thermal sensors, even allows us to record the associated temperature effects. We demonstrate that the deposition area can be deduced by a temperature anomaly, indicating complex isolines associated with local-scale morphology. We did not attempt to compute the volume of the deposition, which in future works can be regularly inferred from DEM differences under consideration of ground control points.

\subsection{Final Remark on Hazard Aspects}

This study is based on one of the first comprehensive measurements realized for decades at this site and may motivate forthcoming researchers to conduct more dedicated surveys or even implement continuous monitoring. Ebeko is a unique laboratory case for studying volcano-tectonic structures and adds a further destination for the study of Vulcanian style behavior.

Ebeko volcano poses a significant hazard to the local population. A 2500-year reconstruction of the eruptive history of Ebeko [78] showed that all kinds of hazards may be expected; the most relevant hazards for the local population are the effusion of lava flows, tephra falls, passing eruptive plumes and lahars, which is further complemented by significant hazards to the aviation industry [79]. In recent years, and during our stay, the volcano sends gases and tephra dominantly to easterly directions, resulting in gases and tephra falls affecting the town of Severo-Kurilsk. Following a catastrophic tsunami in 1952, the town was relocated, unfortunately now being built on alluvial fans of the main rivers Kuz'minka and Matrosskaya originating near Ebeko volcano, with high lahar risk that can reach the town within 20-30 min without any warning [78]. Therefore, close monitoring of the volcano using a combination of in-situ and remote methods is recommended for early warning.

\section{Conclusions}

We achieved a geophysical, geomorphological and structural analysis at Ebeko volcano, a site of intense Vulcanian explosions in 2019. We conducted repeat UAS campaigns and investigated seismic and camera records. The data reveal the occurrence of $\sim 200$ explosive events during the recording period, with an eruption interval of $34 \mathrm{~min}$ on average, although we noted that the explosions and lag times were not regular.

We could generate $\mathrm{cm}$-scale digital terrain models and orthomosaics of the optical and thermal infrared cameras carried by the UAS over the erupting crater. We also found that this new crater follows the general NNE-SSW alignment of the chain of craters that developed since the beginning of the Holocene [80]. The new crater, which initiated as a small explosive funnel on the northern rim of the former North Crater, has now evolved dimensions that are comparable to those of the other craters. The depth of the new crater is even below the water level of the maar-like Middle Crater and is affected by other pre-existing structures. In summary, our analysis (Figure 7) revealed (i) the general eruption frequency and NNE-SSW alignment of partially overlapping craters, (ii) the NNE-SSW alignment of fumarole thermal fields, which are often obscured at smaller scales by morphology, (iii) the expression of $\sim 300$ thermal spots, (iv) the elongation of the newly formed crater and its inner temperature anomaly and (v) the deposition of new materials associated with a single explosion. These results are novel for the Ebeko site, but may also help to better understand other volcanoes where access and structures are 
difficult to reach, highlighting the efficient use of UAS together with time lapse and geophone stations for temporal monitoring.

Author Contributions: Drone data, seismic data and time-lapse camera data were collected by T.R.W., A.B. and M.B. Data processing, SfM, seismic data analysis and kymography by T.R.W. Volcanologic observations and historical analysis by A.B., M.B. and T.K. Dynamic interpretation and discussion contribution by A.A. T.R.W. wrote the manuscript with contributions of all authors. All authors have read and agreed to the published version of the manuscript.

Funding: This is a contribution to VOLCAPSE, a research project funded by the European Research Council under the European Union's H2020 Programme/ERC consolidator grant n. [ERC-CoG 646858].

Acknowledgments: The manuscript benefited from thoughtful reviews by Tom Pering and an anonymous reviewer. We thank Stefan Mikulla for assisting the instrument preparation and Sebastian Heimann for help with his Pyrocko and snuffler python scripts (https://pyrocko.org/). We appreciate the hospitality and organization help by Oleg Stuchinsky and the staff of the seismic observatory of Russian Geophysical Survey in Severo-Kurilsk. We additionally thank to ESA for providing Sentinel-2 data. All data presented is available on request from the corresponding author of this study.

Conflicts of Interest: The authors declare no conflict of interest.

\section{References}

1. Gudmundsson, A. Volcanotectonics: Understanding the Structure, Deformation, and Dynamics of Volcanoes; Cambridge University Press: Cambridge, UK, 2020.

2. Rowland, J.V.; Sibson, R.H. Structural controls on hydrothermal flow in a segmented rift system, Taupo Volcanic Zone, New Zealand. Geofluids 2004, 4, 259-283. [CrossRef]

3. Caliro, S.; Chiodini, G.; Galluzzo, D.; Granieri, D.; La Rocca, M.; Saccorotti, G.; Ventura, G. Recent activity of Nisyros volcano (Greece) inferred from structural, geochemical and seismological data. Bull. Volcanol. 2005, 67, 358-369. [CrossRef]

4. Fridriksson, T.; Kristjansson, B.R.; Armannsson, H.; Margretardottir, E.; Olafsdottir, S.; Chiodini, G. CO2 emissions and heat flow through soil, fumaroles, and steam heated mud pools at the Reykjanes geothermal area, SW Iceland. Appl. Geochem. 2006, 21, 1551-1569. [CrossRef]

5. Muller, D.; Walter, T.R.; Schopa, A.; Witt, T.; Steinke, B.; Gudmundsson, M.T.; Durig, T. High-Resolution Digital Elevation Modeling from TLS and UAV Campaign Reveals Structural Complexity at the 2014/2015 Holuhraun Eruption Site, Iceland. Front. Earth Sci. 2017, 5. [CrossRef]

6. Wilson, L.; Sparks, R.S.J.; Walker, G.P.L. Explosive volcanic eruptions-IV. The control of magma properties and conduit geometry on eruption column behaviour. Geophys. J. R. Astron. Soc. 1980, 63, 117-148. [CrossRef]

7. Thouret, J.C. Volcanic geomorphology-An overview. Earth-Sci. Rev. 1999, 47, 95-131. [CrossRef]

8. Paulsen, T.S.; Wilson, T.J. New criteria for systematic mapping and reliability assessment of monogenetic volcanic vent alignments and elongate volcanic vents for crustal stress analyses. Tectonophysics 2010, 482, 16-28. [CrossRef]

9. Fairbridge, R.W. Crater. In Encyclopedia of Geomorphology; Fairbridge, R.W., Ed.; Reinhold: New York, NY, USA, 1968; pp. 207-218.

10. Jenness, M.H.; Clifton, A.E. Controls on the geometry of a Holocene crater row: A field study from southwest Iceland. Bull. Volcanol. 2009, 71, 715-728. [CrossRef]

11. Mastin, L.G.; Pollard, D.D. Surface Deformation and Shallow Dike Intrusion Processes at Inyo Craters, Long Valley, California. J. Geophys. Res. Solid Earth 1988, 93, 13221-13235. [CrossRef]

12. Lagmay, A.M.F.; de Vries, B.V.; Kerle, N.; Pyle, D.M. Volcano instability induced by strike-slip faulting. Bull. Volcanol. 2000, 62, 331-346. [CrossRef]

13. Schopa, A.; Pantaleo, M.; Walter, T.R. Scale-dependent location of hydrothermal vents: Stress field models and infrared field observations on the Fossa Cone, Vulcano Island, Italy. J. Volcanol. Geotherm. Res. 2011, 203, 133-145. [CrossRef]

14. Pantaleo, M.; Walter, T.R. The ring-shaped thermal field of Stefanos crater, Nisyros Island: A conceptual model. Solid Earth 2014, 5, 183-198. [CrossRef]

15. Hutchison, W.; Mather, T.A.; Pyle, D.M.; Biggs, J.; Yirgu, G. Structural controls on fluid pathways in an active rift system: A case study of the Aluto volcanic complex. Geosphere 2015, 11, 542-562. [CrossRef] 
16. Walter, T.R.; Jousset, P.; Allahbakhshi, M.; Witt, T.; Gudmundsson, M.T.; Hersir, G.P. Underwater and drone based photogrammetry reveals structural control at Geysir geothermal field in Iceland. J. Volcanol. Geotherm. Res. 2020, 391. [CrossRef]

17. Maccaferri, F.; Richter, N.; Walter, T.R. The effect of giant lateral collapses on magma pathways and the location of volcanism. Nat. Commun. 2017, 8, 1097. [CrossRef]

18. Zorn, E.U.; Le Corvec, N.; Varley, N.R.; Salzer, J.T.; Walter, T.R.; Navarro-Ochoa, C.; Vargas-Bracamontes, D.M.; Thiele, S.T.; Mendoza, R.A. Load Stress Controls on Directional Lava Dome Growth at Volcan de Colima, Mexico. Front. Earth Sci. 2019, 7. [CrossRef]

19. Pyle, D.M.; Elliott, J.R. Quantitative morphology, recent evolution, and future activity of the Kameni Islands volcano, Santorini, Greece. Geosphere 2006, 2, 253-268. [CrossRef]

20. Cashman, K.V.; Soule, S.A.; Mackey, B.H.; Deligne, N.I.; Deardorff, N.D.; Dietterich, H.R. How lava flows: New insights from applications of lidar technologies to lava flow studies. Geosphere 2013, 9, 1664-1680. [CrossRef]

21. Patrick, M.R.; Dietterich, H.R.; Lyons, J.J.; Diefenbach, A.K.; Parcheta, C.; Anderson, K.R.; Namiki, A.; Sumita, I.; Shiro, B.; Kauahikaua, J.P. Cyclic lava effusion during the 2018 eruption of Kilauea Volcano. Science 2019, 366, 1213. [CrossRef]

22. Crowley, J.K.; Zimbelman, D.R. Mapping hydrothermally altered rocks on Mount Rainier, Washington, with Airborne Visible/Infrared Imaging Spectrometer (AVIRIS) data. Geology 1997, 25, 559-562. [CrossRef]

23. James, M.R.; Carr, B.; D’Arcy, F.; Diefenbach, A.; Dietterich, H.; Fornaciai, A.; Lev, E.; Liu, E.; Pieri, D.; Rodgers, M.; et al. Volcanological applications of unoccupied aircraft systems (UAS): Developments, strategies, and future challenges. Volcanica 2020, 3, 67-114. [CrossRef]

24. Jordan, B.R. Collecting field data in volcanic landscapes using small UAS (sUAS)/drones. J. Volcanol. Geotherm. Res. 2019, 385, 231-241. [CrossRef]

25. Favalli, M.; Fornaciai, A.; Nannipieri, L.; Harris, A.; Calvari, S.; Lormand, C. UAV-based remote sensing surveys of lava flow fields: A case study from Etna's 1974 channel-fed lava flows. Bull. Volcanol. 2018, 80. [CrossRef]

26. McGonigle, A.J.S.; Aiuppa, A.; Giudice, G.; Tamburello, G.; Hodson, A.J.; Gurrieri, S. Unmanned aerial vehicle measurements of volcanic carbon dioxide fluxes. Geophys. Res. Lett. 2008, 35. [CrossRef]

27. Pering, T.D.; Liu, E.J.; Wood, K.; Wilkes, T.C.; Aiuppa, A.; Tamburello, G.; Bitetto, M.; Richardson, T.; McGonigle, A.J.S. Combined ground and aerial measurements resolve vent-specific gas fluxes from a multi-vent volcano. Nat. Commun. 2020, 11, 3039. [CrossRef]

28. Zorn, E.U.; Walter, T.R.; Johnson, J.B.; Mania, R. UAS-based tracking of the Santiaguito Lava Dome, Guatemala. Sci. Rep. UK 2020. [CrossRef]

29. Nakano, T.; Kamiya, I.; Tobita, M.; Iwahashi, J.; Nakajima, H. Landform Monitoring in Active Volcano by Uav and Sfm-Mvs Technique. Int. Arch. Photogramm. 2014, 40, 71-75. [CrossRef]

30. Syahbana, D.K.; Kasbani, K.; Suantika, G.; Prambada, O.; Andreas, A.S.; Saing, U.B.; Kunrat, S.L.; Andreastuti, S.; Martanto, M.; Kriswati, E.; et al. The 2017-19 activity at Mount Agung in Bali (Indonesia): Intense unrest, monitoring, crisis response, evacuation, and eruption. Sci. Rep. UK 2019, 9. [CrossRef]

31. Darmawan, H.; Walter, T.R.; Brotopuspito, K.S.; Nandaka, I.G.M.A. Morphological and structural changes at the Merapi lava dome monitored in 2012-15 using unmanned aerial vehicles (UAVs). J. Volcanol. Geotherm. Res. 2018, 349, 256-267. [CrossRef]

32. Walter, T.R.; Salzer, J.; Varley, N.; Navarro, C.; Arambula-Mendoza, R.; Vargas-Bracamontes, D. Localized and distributed erosion triggered by the 2015 Hurricane Patricia investigated by repeated drone surveys and time lapse cameras at Volcan de Colima, Mexico. Geomorphology 2018, 319, 186-198. [CrossRef]

33. Schellenberg, B.; Richardson, T.; Watson, M.; Greatwood, C.; Clarke, R.; Thomas, R.; Wood, K.; Freer, J.; Thomas, H.; Liu, E.; et al. Remote sensing and identification of volcanic plumes using fixed-wing UAVs over Volcán de Fuego, Guatemala. J. Field Robot. 2019, 36, 1192-1211. [CrossRef]

34. Watanabe, A.; Kuri, M.; Nagatani, K. Field Report: Autonomous Lake Bed Depth Mapping by a Portable Semi-submersible USV at Mt. Zao Okama Crater Lake. IEEE Int. Symp. Saf. 2016, 214-219.

35. Dering, G.M.; Micklethwaite, S.; Thiele, S.T.; Vollgger, S.A.; Cruden, A.R. Review of drones, photogrammetry and emerging sensor technology for the study of dykes: Best practises and future potential. J. Volcanol. Geotherm. Res. 2019, 373, 148-166. [CrossRef] 
36. Konagai, K.; Kiyota, T.; Shiga, M.; Tomita, H.; Okuda, H.; Kajihara, K. Ground fissures that appeared in aso caldera basin in the 2016 Kumamoto earthquake, Japan. JSCE J. Disaster Fact-Sheets 2016, 1, FS2016-E-0003.

37. Turner, N.R.; Perroy, R.L.; Hon, K. Lava flow hazard prediction and monitoring with UAS: A case study from the 2014-2015 Pāhoa lava flow crisis, Hawai'i. J. Appl. Volcanol. 2017, 6. [CrossRef]

38. Avdeiko, G.P.; Volynets, O.N.; Antonov, A.Y.; Tsvetkov, A.A. Kurile Island-Arc Volcanism - Structural and Petrological Aspects. Tectonophysics 1991, 199, 271-287. [CrossRef]

39. Avdeiko, G.P.; Antonov, A.Y.; Volynets, O.N. Submarine Volcanism and Zoning of the Kuril Island Arc. Nauka, Moscow (528 pp. in Russian). In Submarine Volcanism and Zoning of the Kuril Island Arc; Pushcharovskii, Y.M., Ed.; Nauka: Moscow, Russia, 1992; p. 529.

40. Menyailov, I.A.; Nikitina, L.P.; Shapar, V.N. Results of geochemical monitoring of the activity of Ebeko volcano (Kurile Islands) used for eruption prediction. J. Geodyn. 1985, 3, 259-274. [CrossRef]

41. Kotenko, T.A.; Kotenko, L.V.; Shapar, V.N. Increased Activity on Ebeko Volcano, Paramushir I., North Kurils in 2005-2006. J. Volcanol. Seismol. 2007, 1, 285-295. [CrossRef]

42. Kotenko, T.A.; Panin, G.L.; Balkov, E.V.; Fadeev, D.I. The application of shallow electrical tomography to the study of hydrothermal objects of the Ebeko Volcano (Paramushir Island, Kuriles). Vestn. DVO RAN 2018, 2 , 101-109. [CrossRef]

43. Gorshkov, G. Volcanism and the Upper Mantle: Investigations in the Kurile Island Arc; Springer: New York, NY, USA, 1970; p. 385. [CrossRef]

44. Rychagov, S.N.; Belousov, V.I.; Kotenko, T.; Kotenko, L.V. Gas-Hydrothermal System of the Ebeko Volcano (Paramushir Island)—Zone of Ascending Fluid Flow in the Structure of the North-Kuril Geothermal Deposit. In Proceedings of the World Geothermal Congress, Bali, Indonesia, 25-29 April 2010; pp. 1-4.

45. Martynov, Y.A.; Khanchuk, A.I.; Kimura, J.I.; Rybin, A.V.; Martynov, A.Y. Geochemistry and Petrogenesis of Volcanic Rocks in the Kuril Island Arc. Petrology 2010, 18, 489-513. [CrossRef]

46. Shevko, E.P.; Bortnikova, S.B.; Abrosimova, N.A.; Kamenetsky, V.S.; Bortnikova, S.P.; Panin, G.L.; Zelenski, M. Trace Elements and Minerals in Fumarolic Sulfur: The Case of Ebeko Volcano, Kuriles. Geofluids 2018. [CrossRef]

47. Gorshkov, G. The Volcanism of the Kurile Island Arc; Nauka: Moscow, Russia, 1967; pp. 1-287.

48. Menyailov, I.A.; Nikitina, L.P.; Khramova, G.G. The gashydrothermal eruption of Ebeko volcano in February-April, 1967. Bull. Volcanot. Stn. 1969, 45, 3-6.

49. Basov, E.I.; van Weering, T.C.E.; Gaedike, C.; Baranov, B.V.; Lelikov, E.P.; Obzhirov, A.I.; Belykh, I.N. Seismic fades and specific character of the bottom simulating reflector on the western margin of Paramushir Island, Sea of Okhotsk. Geo. Mar. Lett. 1996, 16, 297-304. [CrossRef]

50. Kalacheva, E.; Kotenko, T.; Voloshina, E. Chemical weathering fluxes from Paramushir volcanic island (Kuril Island arc, Russia). E3s Web Conf. 2019, 98. [CrossRef]

51. Kotenko, T.A.; Kotenko, L.V. Hydrothermal manifestations and heat flux of volcanoes Ebeko and Krasheninnikov (Paramushir, Kuril Islands). Vestn. Kraunts 2006, 1, 129-137.

52. Melnikov, D.; Malik, N.; Kotenko, T. A New Estimate of Gas Emissions from Ebeko Volcano, Kurile Islands. In Proceedings of the Goldschmidt Conference, Yokohama, Japan, 26 June-1 July 2016; p. 2047.

53. Taran, Y.; Zelenski, M.; Chaplygin, I.; Malik, N.; Campion, R.; Inguaggiat, S.; Pokrovsky, B.; Kalacheva, E.; Melnikov, D.; Kazahaya, R.; et al. Gas Emissions From Volcanoes of the Kuril Island Arc (NW Pacific): Geochemistry and Fluxes. Geochem. Geophys. Geosyst. 2018, 19, 1859-1880. [CrossRef]

54. Panin, G.L.; Gora, M.P.; Bortnikova, S.P.; Shevko, E.P. Subsurface structure of the northeastern fumarole field of the Ebeko Volcano (Paramushir Island) according to the data of geoelectrical and geochemical studies. Russ. J. Pac. Geol. 2015, 9, 301-311. [CrossRef]

55. Kotenko, T.A.; Kotenko, L.V.; Sandimirova, E.I.; Shapar, V.N.; Timofeeva, I.F. Eruption activity of Ebeko volcano (Paramushir i.) in 2010-2011. Vestn. Kraunts 2012, 1, 160-167.

56. Kalacheva, E.; Taran, Y.; Kotenko, T.; Hattori, K.; Kotenko, L.; Solis-Pichardo, G. Volcano-hydrothermal system of Ebeko volcano, Paramushir, Kuril Islands: Geochemistry and solute fluxes of magmatic chlorine and sulfur. J. Volcanol. Geotherm. Res. 2016, 310, 118-131. [CrossRef]

57. Spampinato, L.; Calvari, S.; Oppenheimer, C.; Boschi, E. Volcano surveillance using infrared cameras. Earth-Sci. Rev. 2011, 106, 63-91. [CrossRef]

58. Ball, M.; Pinkerton, H. Factors affecting the accuracy of thermal imaging cameras in volcanology. J. Geophys. Res.-Solid Earth 2006, 111. [CrossRef] 
59. Stevenson, J.A.; Varley, N. Fumarole monitoring with a handheld infrared camera; Volcan de Colima, Mexico, 2006-2007. J. Volcanol. Geotherm. Res. 2008, 177, 911-924. [CrossRef]

60. Westoby, M.J.; Brasington, J.; Glasser, N.F.; Hambrey, M.J.; Reynolds, J.M. 'Structure-from-motion' photogrammetry: A low-cost, effective tool for geoscience applications. Geomorphology 2012, 179, 300-314. [CrossRef]

61. Kalacska, M.; Lucanus, O.; Arroyo-Mora, J.P.; Laliberté, É.; Elmer, K.; Leblanc, G.; Groves, A. Accuracy of 3d landscape reconstruction without ground control points using different uas platforms. Drones 2020, 4, 13. [CrossRef]

62. Heimann, S.; Vasyura-Bathke, H.; Sudhaus, H.; Isken, M.P.; Kriegerowski, M.; Steinberg, A.; Dahm, T. A Python framework for efficient use of pre-computed Green's functions in seismological and other physical forward and inverse source problems. Solid Earth 2019, 10, 1921-1935. [CrossRef]

63. Witt, T.; Walter, T.R. Video monitoring reveals pulsating vents and propagation path of fissure eruption during the March 2011 Pu'u 'O'o eruption, Kilauea volcano. J. Volcanol. Geotherm. Res. 2017, 330, 43-55. [CrossRef]

64. Witt, T.; Walter, T.R.; Muller, D.; Gudmundsson, M.T.; Schopa, A. The Relationship Between Lava Fountaining and Vent Morphology for the 2014-2015 Holuhraun Eruption, Iceland, Analyzed by Video Monitoring and Topographic Mapping. Front. Earth Sci. 2018, 6. [CrossRef]

65. Harris, A. Thermal Remote Sensing of Active Volcanoes: A User's Manual; Cambridge University Press: Cambridge, UK, 2013. [CrossRef]

66. Heap, M.J.; Troll, V.R.; Kushnir, A.R.L.; Gilg, H.A.; Collinson, A.S.D.; Deegan, F.M.; Darmawan, H.; Seraphine, N.; Neuberg, J.; Walter, T.R. Hydrothermal alteration of andesitic lava domes can lead to explosive volcanic behaviour. Nat. Commun. 2019, 10. [CrossRef]

67. Akbashev, R.F.; Firstov, P.P. The response of the atmospheric electric potential gradient to the ash clouds of v. Shiveluch and v. Ebeko (Peninsula Kamchatka, Island Paramushir, Russia). IOP Conf. Ser. Mater. Sci. Eng. 2019, 698, 044042. [CrossRef]

68. Pering, T.D.; Tamburello, G.; McGonigle, A.J.S.; Aiuppa, A.; James, M.R.; Lane, S.J.; Sciotto, M.; Cannata, A.; Patane, D. Dynamics of mild strombolian activity on Mt. Etna. J. Volcanol. Geotherm. Res. 2015, 300, 103-111. [CrossRef]

69. Ripepe, M.; Donne, D.D.; Harris, A.; Marchetti, E.; Ulivieri, G. Dynamics of Strombolian Activity. In The Stromboli Volcano: An Integrated Study of the 2002-2003 Eruption; Calvari, S., Inguaggiato, S., Puglisi, G., Ripepe, M., Rosi, M., Eds.; AGU Geophysical Monograph Series; John Wiley \& Sons: Hoboken, NJ, USA, 2013; pp. 39-48. [CrossRef]

70. Eibl, E.P.S.; Hainzl, S.; Vesely, N.I.K.; Walter, T.R.; Jousset, P.; Hersir, G.P.; Dahm, T. Eruption Interval Monitoring at Strokkur Geyser, Iceland. Geophys. Res. Lett. 2020, 47. [CrossRef]

71. Inza, L.A.; Metaxian, J.P.; Mars, J.I.; Bean, C.J.; O’Brien, G.S.; Macedo, O.; Zandomeneghi, D. Analysis of dynamics of vulcanian activity of Ubinas volcano, using multicomponent seismic antennas. J. Volcanol. Geotherm. Res. 2014, 270, 35-52. [CrossRef]

72. Pyle, D.M. The thickness, volume and grainsize of tephra fall deposits. Bull. Volcanol. 1989, 51, 1-15. [CrossRef]

73. Cioni, R.; Longo, A.; Macedonio, G.; Santacroce, R.; Sbrana, A.; Sulpizio, R.; Andronico, D. Assessing pyroclastic fall hazard through field data and numerical simulations: Example from Vesuvius. J. Geophys. Res. Solid Earth 2003, 108. [CrossRef]

74. Marzocchi, W.; Sandri, L.; Selva, J. BET_VH: A probabilistic tool for long-term volcanic hazard assessment. Bull. Volcanol. 2010, 72, 705-716. [CrossRef]

75. Walker, G.P.L.; Croasdale, R. Characteristics of some basaltic pyroclastics. Bull. Volcanol. 1971, 35, 303-317. [CrossRef]

76. Yang, Q.Y.; Bursik, M.; Pitman, E.B. A new method to identify the source vent location of tephra fall deposits: Development, testing, and application to key Quaternary eruptions of Western North America (vol 81, 51, 2019). Bull. Volcanol. 2019, 81. [CrossRef]

77. Klawonn, M.; Houghton, B.F.; Swanson, D.A.; Fagents, S.A.; Wessel, P.; Wolfe, C.J. Constraining explosive volcanism: Subjective choices during estimates of eruption magnitude. Bull. Volcanol. 2014, 76. [CrossRef]

78. Melekestsev, I.V.; Dvigalo, V.N.; Kirianov, V.Y. Ebeko volcano (Kuril Islands): History of the eruptive activity and a future volcanic hazard. Vulcanol. Seismol. 1993, 3, 69-81. 
79. Kirianov, V.Y. Volcanic ash in Kamchatka as a source of potential hazard to air traffic. In Proceedings of the Volcanic Ash and Aviation Safety: First International Symposium, Seattle, DC, USA, 8-12 July 1991; pp. 57-64.

80. Melekestsev, I.V.; Braitseva, O.A.; Ponomareva, V.V.; Sulerzhitskiy, L.D. Age and Dynamics of Formation of Active Volcanos of Kuril-Kamchatka Region. Izv. Akad. Nauk SSSR Seriya Geol. 1990, 4, 17-31.

(C) 2020 by the authors. Licensee MDPI, Basel, Switzerland. This article is an open access article distributed under the terms and conditions of the Creative Commons Attribution (CC BY) license (http://creativecommons.org/licenses/by/4.0/). 